\title{
Penerapan Metode Triple Exponential Smoothing Dalam Prediksi Penanaman Bibit Kelapa Sawit Pada PT. Palmanco Inti Sawit
}

The Application of the Triple Exponential Smoothing Method in the Prediction of Planting Oil Palm Seeds at PT. Palmanco Inti Sawit

\author{
Debby Santika ${ }^{1}$, Ratna Sri Hayati ${ }^{2}$, Ivi Lazuli ${ }^{3}$ \\ ${ }^{1}$ Jurusan Teknik InformatikaUniversitas Potensi Utama \\ ${ }^{2,3}$ Dosen Jurusan Sistem Informasi Universitas Potensi Utama \\ ${ }^{1,2,3}$ Universitas Potensi Utama, K.L. Yos Sudarso KM 6,5 No. 3A Tj. Mulia-Medan \\ Email :debbysantika90@gmail.com ${ }^{l,}$,ratnayach@gmail.com², ivilazuli2@gmail.com³
}

\begin{abstract}
ABSTRAK
PT. Palmanco Inti Sawit adalah perusahaan yang bergerak di bidang produksi dan penjualan hasil olahan sawit. Namun ada beberapa kendala yang dihadapi oleh perusahaan yaitu sistem yang berjalan masih tergolong semi komputerisasi dalam proses penentuan prediksi penanaman bibit kelapa sawit dan pembuatan laporan prediksi penanaman bibit kelapa sawit membutuhkan waktu yang cukup lama Karena sistem yang berjalan pada perusahaan masih kurang akurat atau tergolong semi komputerisasi. Kendala yang dihadapi oleh PT. Palmanco Inti Sawit adalah bagian lapangan harus mendata satu persatu hasil panen sawit yang terjadi sehingga kurang akurat dalam penentuan perhitungan prediksi penanaman bibit kelapa sawit, dan proses perhitungan prediksi pembibitan kelapa sawit masih menggunakan perhitungan sederhana yaitu dengan menggunakan aplikasi Microsoft excel, sering terjadi kesalahan dalam perhitungan prediksi dan jumlah penanaman bibit kelapa sawit tidak sinkron dengan data pembibitan kelapa sawit sesungguhnya, yang menjadi bahan penelitian penulis adalah data penanaman bibit sawit periode tahun 2019 sampai dengan April 2020. Dibutuhkan metode dalam perhitungan prediksi pembibitan kelapa sawit ke periode berikutnya sehingga dapat mempermudah bagian pembibitan dalam menentukan jumlah bibit yang akan diperlukan pada periode yang akan datang serta dalam pembuatan laporan prediksi pembibitan penanaman bibit kelapa sawit dapat diperoleh dengan efektif.
\end{abstract}

Kata Kunci : Peramalan, Penanaman, Visual Studio, Sql Server

\section{ABSTRACT}

PT. Palmanco Inti Sawit is a company engaged in the production and sale of processed palm oil products. However, there are several obstacles faced by the company, namely the system that is running is still classified as semi-computerized in the process of determining predictions for planting oil palm seeds and preparing reports on prediction of planting oil palm seeds which takes quite a long time because the system running at the company is still inaccurate or classified as semi-computerized. . Constraints faced by PT. Palmanco Inti Sawit is that part of the field must record one by one the yields of palm oil that occur so that it is inaccurate in determining the prediction calculation for oil palm seedlings, and the process of calculating the prediction of oil palm seedlings is still using simple calculations using the Microsoft Excel application, errors often occur in calculations Predictions and the number of oil palm seedlings planted are out of sync with actual oil palm nursery data, which is the research material for the authors is the planting data for oil palm seedlings for the period 2019 to April 2020. A method is needed in calculating the prediction of oil palm nurseries to the next period so that it can facilitate the nursery section In determining the number of seeds that will be needed in the coming period as well as in making reports of prediction of oil palm seedlings planting can be obtained effectively.

Keywords: Forecasting, Planting, Visual Studio, Sql Server 


\section{PENDAHULUAN}

Ramalan (forecast) merupakan dugaan atau perkiraan mengenai terjadinya suatu kejadian atau peristiwa di waktu yang akan datang. Ramalan ini sangat berguna dalam berbagai bidang kehidupan, terutama dalam rangka perencanaan untuk mengantisipasi berbagai keadaan yang terjadi pada masa yang akan datang.

PT. Palmanco Inti Sawit adalah perusahaan yang bergerak di bidang produksi dan penjualan hasil olahan sawit. Namun ada beberapa kendala yang dihadapi oleh perusahaan yaitu sistem yang berjalan masih tergolong semi komputerisasi dalam proses penentuan prediksi penanaman bibit kelapa sawit dan pembuatan laporan prediksi penanaman bibit kelapa sawit membutuhkan waktu yang cukup lama Karena sistem yang berjalan pada perusahaan masih kurang akurat atau tergolong semi komputerisasi. Kendala yang dihadapi oleh PT. Palmanco Inti Sawit adalah bagian lapangan harus mendata satu persatu hasil panen sawit yang terjadi sehingga kurang akurat dalam penentuan perhitungan prediksi penanaman bibit kelapa sawit, dan proses perhitungan prediksi pembibitan kelapa sawit masih menggunakan perhitungan sederhana yaitu dengan menggunakan aplikasi Microsoft excel, sering terjadi kesalahan dalam perhitungan prediksi dan jumlah penanaman bibit kelapa sawit tidak sinkron dengan data pembibitan kelapa sawit sesungguhnya, yang menjadi bahan penelitian penulis adalah data penanaman bibit sawit periode tahun 2019 sampai dengan April 2020.

Dibutuhkan metode dalam perhitungan prediksi pembibitan kelapa sawit ke periode berikutnya sehingga dapat mempermudah bagian pembibitan dalam menentukan jumlah bibit yang akan diperlukan pada periode yang akan datang serta dalam pembuatan laporan prediksi pembibitan penanaman bibit kelapa sawit dapat diperoleh dengan efektif. Dengan menerapkan metode triple exponential smoothing dapat membantu perusahaan dalam mengatasi masalah yang dihadapi oleh perusahaan. Karena triple exponential smoothing lebih efektif serta perhitungan dilakukan sebanyak 3 kali perhitungan, sehingga tingkat kesalahan dalam perhitungan peramalan lebih sedikit serta metode Triple Exponential Smoothing digunakan ketika terdapat unsur trend dan perilaku musiman yang ditunjukkan pada data, dengan merancang dan membangun sistem informasi prediksi penanaman bibit kelapa sawit akan dapat membantu PT. Palmanco Inti Sawit dalam melakukan penghitungan prediksi penanaman bibit kelapa sawit.

Hasil dari suatu peramalan penanaman bibit kelapa sawit merupakan pernyataan atau penilaian terhadap kondisi masa depan mengenai penanaman bibit kelapa sawit sebagai proyeksi teknis potensial untuk jangka waktu tertentu. Meskipun demikian hasil perkiraan yang diperoleh mungkin saja tidak sama dengan rencana. Pemanfaatan ramalan penanaman bibit kelapa sawit akan digunakan untuk informasi penanaman bibit kelapa sawit untuk memprediksi tingkat penanaman bibit kelapa sawit pada hari yang akan datang. Peramalan penanaman bibit kelapa sawit yang akan diterapkan dengan menggunakan metode Triple Exponential Smoothing, dengan tujuan untuk memprediksi penanaman bibit kelapa sawit pada 1 periode (per bulan).

\section{METODOLOGI PENELITIAN}

Di dalam menyelesaikan penelitian ini penulis menggunakan 2 (dua) metode studi yaitu:

1. Studi Lapangan

Merupakan metode yang dilakukan dengan mengadakan studi langsung ke lapangan untuk mengumpulkan data yaitu peninjauan langsung ke lokasi studi. Adapun teknik pengumpulan data yang dilakukan penulis adalah :

a. Pengamatan (Observation)

Penulis melakukan pengamatan langsung pada PT. Palmanco Inti Sawit, adapun data yang diamati oleh penulis terdiri dari data bibit, data supplier, dan data penanaman bibit kelapa sawit pada PT. Palmanco Inti Sawit.

b. Wawancara

Teknik ini secara langsung bertatap muka dengan pihak bersangkutan untuk mendapatkan penjelasan dari masalah-masalah yang sebelumnya kurang jelas yaitu tentang mekanisme 
sistem yang digunakan pada perusahaan dan juga untuk meyakinkan bahwa data yang diperoleh dikumpulkan benar-benar akurat. Dan mengajukan pertanyaan kepada bagian pembibitan dengan Bapak Budiman Herianto, ST . Adapun pertanyaan yang diajukan penulis adalah:
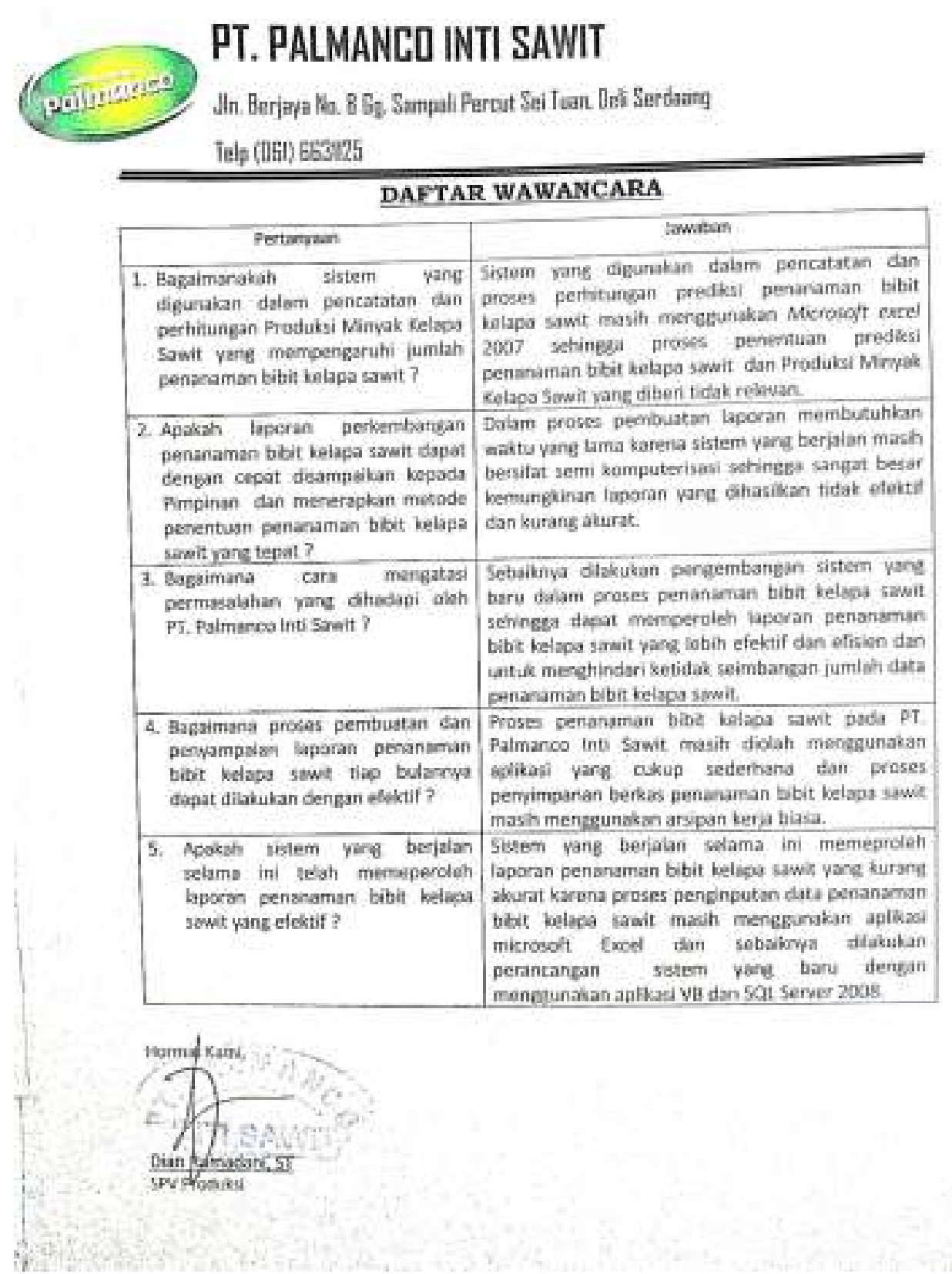

Gambar 1. Daftar Wawancara

\section{2. $\quad$ Studi Kepustakaan (Library Research)}

Penulis melakukan studi pustaka untuk memperoleh data-data yang berhubungan dengan penulisan penelitian dari berbagai sumber bacaan seperti buku panduan pembuatan aplikasi visual studio 2010, manajemen data, dan buku atau jurnal yang membahas tentang konsep penanaman bibit.

Metode yang digunakan penulis dalam megembangkan sistem yang akan dibangun adalah metode kerangka Fish Bone. Fish Bone dan dapat dilihat pada gambar 2. 


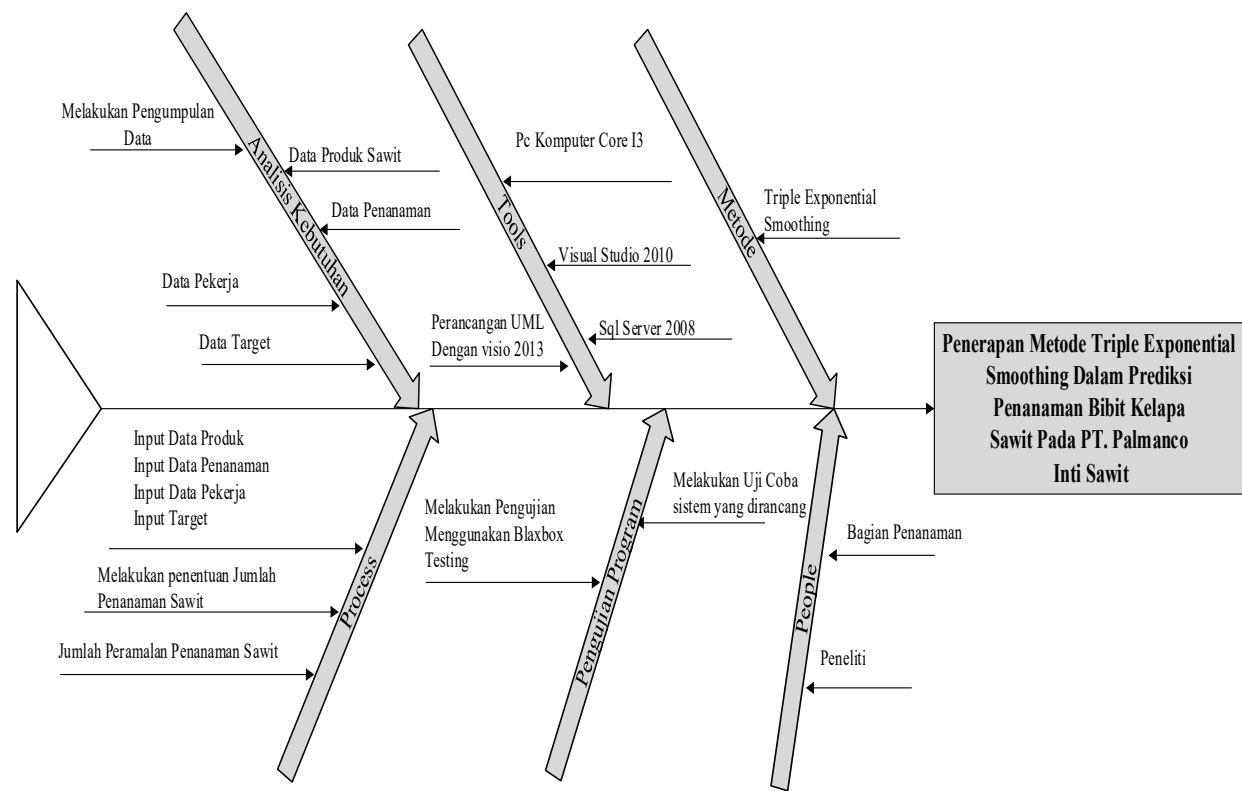

Gambar 2. Kerangka Fishbone

Keterangan :

1. Analisa Kebutuhan

Pada tahapan ini peneliti mengumpulkan data-data teori yang terkait dengan penelitian. Adapun data penelitian yang menjadi penelitian oleh penulis adalah data bibit kelapa sawit Periode Januari 2019 - April 2020.

2. Tools

Pada tahap ini dilakukan penentuan spesifikasi komputer, melakukan proses design interface dengan menggunakan Visual Studio 2010 dan Sql Server 2008 dan perancangan program menggunakan pemodelan UML yaitu use case diagram, class diagram, activity diagram dan sequence diagram. Desain sistem pada aplikasi menggunakan pemrograman berbasis desktop. 3. Metode

Pada tahapan ini peneliti memilih metode memilih metode Triple Exponential Smoothing dalam penentuan penanaman bibit kelapa sawit pada PT. Palmanco Inti Sawit.

4. Process

Pada tahapan ini peneliti melakukan tahapan proses penelitian mulai dari menentukan data produk sawit, data penanaman, data target dan data pekerja. Setelah itu peneliti melakukan penentuan jumlah penanaman bibit kelapa sawit tiap periodenya.

5. Pengujian Program

Pengujian program secara teori dilakukan dengan menggunakan blackbox testing dimana pengujian dilakukan satu persatu. Pengujian secara praktek menggunakan pemrograman berbasis desktop dimana pengujian dilakukan dengan menguji setiap komponen pada aplikasi satu persatu.

6. People

Pada tahapan ini peneliti dan bagian lapangan khususnya dalam penanaman bibit kelapa sawit adalah pengguna sistem yang telah dirancang.

\section{HASIL DAN PEMBAHASAN}

PT. Palmanco Inti Sawit adalah perusahaan yang bergerak di bidang Bibitsi dan penjualan hasil olahan sawit. Namun ada beberapa kendala yang dihadapi oleh perusahaan yaitu sistem yang berjalan masih tergolong semi komputerisasi dalam proses prediksi penanaman bibit sawit. Kendala yang dihadapi oleh PT. Palmanco Inti Sawit adalah bagian lapangan harus mendata satu persatu hasil panen sawit yang terjadi sehingga kurang akurat dalam pembuatan laporan prediksi penanaman bibit kelapa sawit, proses perhitungan prediksi pembibitan kelapa sawit masih menggunakan perhitungan sederhana yaitu dengan menggunakan aplikasi 
Microsoft excel sehingga dalam penyampaian laporan prediksi pembibitan kelapa sawit tidak efektif dan efisien, sering terjadi kesalahan dalam perhitungan prediksi dan jumlah penanaman bibit kelapa sawit tidak sinkron dengan data pembibitan kelapa sawit sesungguhnya.

Dibutuhkan metode dalam perhitungan pembibitan kelapa sawit ke periode berikutnya. Dengan menerapkan metode triple exponential smoothing dapat membantu perusahaan dalam mengatasi masalah yang dihadapi oleh perusahaan. Karena triple exponential smoothing digunakan ketika terdapat unsur trend dan perilaku musiman yang ditunjukkan pada data, dengan merancang dan membangun sistem informasi prediksi penanaman bibit kelapa sawit akan dapat membantu PT. Palmanco Inti Sawit dalam melakukan penghitungan prediksi penanaman bibit kelapa sawit.

\section{Studi Kasus Metode TES}

1. Kasus Metode Triple Exponential Smoothing

Dengan menggunakan metode Triple Exponential Smoothing, ketentuan nilai $a \alpha$ dan $\beta \beta$ yang digunakan adalah :

Tabel 1. Nilai $\alpha \alpha$ dan $\beta \beta$

\begin{tabular}{|r|c|c|}
\hline No & $\alpha$ & $\beta$ \\
\hline 1 & 0.1 & 0.1 \\
\hline 2 & 0.2 & 0.2 \\
\hline 3 & 0.3 & 0.3 \\
\hline 4 & 0.4 & 0.4 \\
\hline 5 & 0.5 & 0.5 \\
\hline 6 & 0.6 & 0.6 \\
\hline 7 & 0.7 & 0.7 \\
\hline 8 & 0.8 & 0.8 \\
\hline 9 & 0.9 & 0.9 \\
\hline
\end{tabular}

Perusahaan melakukan Penanaman bibit sawit Pisifera selama 1 (satu) tahun pada periode Januari 2019 - April 2020 dengan data sebagai berikut :

Tabel 2. Data Penanaman

\begin{tabular}{|l|c|}
\hline \multicolumn{1}{|c|}{ Bulan } & Penanaman \\
\hline Januari & 140 Unit \\
\hline Februari & 159 Unit \\
\hline Maret & 136 Unit \\
\hline April & 157 Unit \\
\hline Mei & 173 Unit \\
\hline Juni & 131 Unit \\
\hline Juli & 177 Unit \\
\hline Agustus & 188 Unit \\
\hline September & 154 Unit \\
\hline Oktober & 179 Unit \\
\hline November & 180 Unit \\
\hline Desember & 160 Unit \\
\hline Januari & 150 Unit \\
\hline Februari & 169 Unit \\
\hline Maret & 140 Unit \\
\hline April & 160 Unit \\
\hline
\end{tabular}

Maka akan meramalkan Periode ke-17 dengan nilai $\alpha=0.3 \alpha=0.3$.

$\checkmark \quad$ Tahap pertama Pemulusan Eksponensial Tunggal: $S_{t}^{\prime}=a_{X_{t}}+(1-a) S^{\prime} t-1$ 
1. Pemulusan exponential pada Bulan Januari

$\mathrm{S}_{1}^{\prime}=140$

2. Pemulusan exponential pada Bulan Februari

$\mathrm{S}_{2}^{\prime}=(0,3) 159+(1-0,3) 140$

$\mathrm{S}_{2}^{\prime}=47.7+98$

$=145.7$

3. Pemulusan exponential pada Bulan Maret

$\mathrm{S}_{3}=(0,3) 136+(1-0,3) 145.7$

$\mathrm{S}_{3}^{\prime}=40.8+101.99$

$=142.79$

4. Pemulusan exponential pada Bulan April

$\mathrm{S}_{4}^{\prime}=(0,3) 157+(1-0,3) 142.79$

$\mathrm{S}^{\prime}{ }_{4}=47.1+99.95$

$\mathrm{S}^{\prime}{ }_{4}=147.05$

5. Pemulusan exponential pada Bulan Mei

$\mathrm{S}^{\prime}=(0,3) 173+(1-0,3) 147.05$

$\mathrm{S}^{\prime}=51.9+102.9$

$\mathrm{S}^{\prime}=154.8$

6. Pemulusan exponential pada

Bulan Juni

$\mathrm{S}_{6}{ }_{6}=(0,3) 131+(1-0,3) 154.8$

$\mathrm{S}_{6}^{\prime}=39.3+108.36$

$\mathrm{S}^{\prime}{ }_{6}=147.66$

7. Pemulusan exponential pada

Bulan Juli

$\mathrm{S}_{7}^{\prime}=(0,3) 177+(1-0,3) 147.66$

$\mathrm{S}^{\prime}{ }_{7}=53.1+103.36$

$\mathrm{S}^{\prime}{ }_{7}=156.46$

8. Pemulusan exponential pada

Bulan Agustus

$\mathrm{S}_{8}^{\prime}=(0,3) 188+(1-0,3) 156.46$

$\mathrm{S}^{\prime}{ }_{8}=56.4+109.52$

$\mathrm{S}_{8}^{\prime}=165.92$

9. Pemulusan exponential pada

Bulan September
$\mathrm{S}_{9}^{\prime}=(0,3) 154+(1-0,3) 165.92$

$\mathrm{S}^{\prime}{ }_{9}=46.2+116.14$

$\mathrm{S}_{9}^{\prime}=162.34$

10. Pemulusan exponential pada

Bulan Oktober

$\mathrm{S}^{\prime}{ }_{10}=(0,3) 179+(1-0,3) 162.34$

$\mathrm{S}^{\prime}{ }_{10}=53.7+113.63$

$\mathrm{S}^{\prime}{ }_{10}=167.33$

11. Pemulusan exponential pada

Bulan November

$\mathrm{S}^{\prime}{ }_{11}=(0,3) 180+(1-0,3) 167.33$

$\mathrm{S}^{\prime}{ }_{11}=54+117.13$

$\mathrm{S}^{\prime}{ }_{11}=171.13$

12. Pemulusan exponential pada

Bulan Desember

$\mathrm{S}^{\prime}{ }_{12}=(0,3) 160+(1-0,3) 171.13$

$\mathrm{S}^{\prime}{ }_{12}=48+119.79$

$\mathrm{S}^{\prime}{ }_{12}=167.79$

13. Pemulusan exponential pada

Bulan Januari

$\mathrm{S}^{\prime}{ }_{13}=(0,3) 150+(1-0,3) 167.79$

$\mathrm{S}^{\prime}{ }_{13}=45+117.453$

$\mathrm{S}^{\prime}{ }_{13}=162.453$

14. Pemulusan exponential pada

Bulan Februari

$\mathrm{S}^{\prime}{ }_{14}=(0,3) 169+(1-0,3) 162.453$

$\mathrm{S}^{\prime}{ }_{14}=50.7+113.717$

$\mathrm{S}^{\prime}{ }_{14}=164.417$

15. Pemulusan exponential pada

Bulan Maret

$\mathrm{S}^{\prime}{ }_{15}=(0,3) 140+(1-0,3) 164.417$

$\mathrm{S}^{\prime}{ }_{15}=42+115.091$

$\mathrm{S}^{\prime}{ }_{15}=157.091$

16. Pemulusan exponential pada

Bulan April

$\mathrm{S}^{\prime}{ }_{16}=(0,3) 160+(1-0,3) 157.091$

$\mathrm{S}^{\prime}{ }_{16}=48+109.9637$

$\mathrm{S}^{\prime}{ }_{16}=157.964$

\footnotetext{
$\begin{array}{ll}\checkmark & \text { Tahap pertama Pemulusan E } \\ 1 . & \text { Pemulusan Eksponensial Ganda }\end{array}$

Januari

S" $1=140$

2. Pemulusan Eksponensial Ganda

Februari

$S^{\prime \prime} 2=(0,3) 145.7+(1-0,3) 140$

$S^{\prime \prime} 2=43.71+98$

$\mathrm{S} " 2=141.71$

3. Pemulusan Eksponensial Ganda

Maret

$\mathrm{S} " 3=(0,3) 142.79+(1-0,3) 141.71$

$\mathrm{S}^{\prime \prime} 3=42.83+99.19$

$\mathrm{S}$ '3 $=142.02$
}
4. Pemulusan Eksponensial Ganda April
S"4= $(0,3) 147.05+(1-0,3) 142.02$
S" $4=44.11+99.41$
S" $4=143.52$
5. Pemulusan Eksponensial Ganda
Mei
$\mathrm{S}^{\prime \prime} 5=(0,3) 154.8+(1-0,3) 143.52$
$S^{\prime \prime} 5=46.11+100.46$
S" $5=146.9$
6. Pemulusan Eksponensial Ganda
Juni
S"6= (0,3) $147.66+(1-0,3) 146.9$


$\mathrm{S}^{\prime \prime} 6=44.9+102.83$

S"6 $=147.12$

7. Pemulusan Eksponensial Ganda

Juli

$S^{\prime \prime} 7=(0,3) 156.46+(1-0,3) 147.12$

$S^{\prime \prime} 7=46.93+102.98$

$\mathrm{S} " 7=149.91$

8. Pemulusan Eksponensial Ganda Agustus

$\mathrm{S} " 8=(0,3) 165.92+(1-0,3) 149.91$

$\mathrm{S} " 8=49.77+104.93$

S"8 $=154.7$

9. Pemulusan Eksponensial Ganda September

$S^{\prime \prime} 9=(0,3) 162.34+(1-0,3) 154.7$

$\mathrm{S}^{\prime \prime} 9=48.70+108.29$

S"9 $=156.99$

10. Pemulusan Eksponensial Ganda

Oktober

S"10 = (0,3) $167.33+(1-0,3) 156.99$

S"10 $=50.19+109.89$

S"10 $=160.08$

11. Pemulusan Eksponensial Ganda November

S"11 = $(0,3) 171.13+(1-0,3) 160.08$

S"11 $=51.33+112.05$

S"11 $=163.38$
12. Pemulusan Eksponensial Ganda Desember

S"12 = $(0,3) 167.79+(1-0,3) 163.38$

S"12 $=50.33+114.36$

$\mathrm{S}^{\prime \prime} 12=164.69$

13. Pemulusan Eksponensial Ganda Januari

$S^{\prime \prime} 13=(0,3) 162.453+(1-0,3) 164.69$

S"13 $=48.736+115.528$

$\mathrm{S} " 13=164.019$

14. Pemulusan Eksponensial Ganda

Februari

S"14 = $(0,3) 164.417+(1-0,3)$

164.019

S"14= $49.325+114.813$

S"14 $=164.69$

15. Pemulusan Eksponensial Ganda

Maret

S"15 = (0,3) 157.091+(1-0,3) 163.38

$S^{\prime \prime} 15=50.33+114.36$

$\mathrm{S} " 15=162.05$

16. Pemulusan Eksponensial Ganda

April

S"16= $=(0,3) 157.964+(1-0,3)$

164.138

S"16 $=47.127+114.897$

S"16=160.83

\footnotetext{
$\checkmark \quad$ Langkah Perhitungan Ekponensial Januari

$\mathrm{S}^{\prime \prime \prime}{ }_{\mathrm{t}}=140$

2. Pemulusan nilai trend pada bulan Februari

$\mathrm{S}^{\prime \prime \prime}{ }_{\mathrm{t}}=0.3(141.71)+0.7(140)$

$\mathrm{S}^{\prime \prime \prime}{ }_{t}=42.51+98$

$\mathrm{S}^{\prime \prime \prime}{ }_{\mathrm{t}}=140.51$

3. Pemulusan nilai trend pada bulan

Maret

$\mathrm{S}^{\prime \prime \prime}{ }_{\mathrm{t}}=0.3(142.02)+0.7(140.51)$

$\mathrm{S}^{\prime \prime \prime}{ }_{\mathrm{t}}=42.60+98.35$

$\mathrm{S}^{\prime \prime \prime}{ }_{\mathrm{t}}=140.95$

4. Pemulusan nilai trend pada bulan

April

$\mathrm{S}^{\prime \prime \prime}{ }_{t}=0.3(143.52)+0.7(140.95)$

$\mathrm{S}^{\prime \prime \prime}{ }_{\mathrm{t}}=43.05+98.66$

$\mathrm{S}^{\prime \prime \prime}{ }_{\mathrm{t}} \quad=141.71$

5. Pemulusan nilai trend pada bulan

Mei

$\mathrm{S}^{\prime \prime \prime}{ }_{\mathrm{t}}=0.3(146.9)+0.7(141.71)$

$\mathrm{S}^{\prime \prime \prime}{ }_{\mathrm{t}}=44.07+99.19$

$\mathrm{S}^{\prime \prime \prime}{ }_{\mathrm{t}}=143.26$

6. Pemulusan nilai trend pada bulan Juni
}

$\begin{array}{ll}\text { ap Tiga : } & \mathrm{S}^{\prime \prime \prime}{ }_{\mathrm{t}}=a \mathrm{~S}^{\prime \prime}{ }_{\mathrm{t}}+(1-a) \mathrm{S}^{\prime \prime}{ }_{\mathrm{t}}-1 \\ \mathrm{~S}^{\prime \prime \prime}{ }_{\mathrm{t}} & =0.3(147.12)+0.7(143.26) \\ \mathrm{S}^{\prime \prime \prime}{ }_{\mathrm{t}} & =44.13+100.28 \\ \mathrm{~S}^{\prime \prime \prime}{ }_{\mathrm{t}} & =144.41 \\ 7 . & \text { Pemulusan nilai trend pada bulan } \\ \mathrm{Juli} & \\ \mathrm{S}^{\prime \prime \prime}{ }_{\mathrm{t}} & =0.3(149.91)+0.7(144.41) \\ \mathrm{S}^{\prime \prime \prime}{ }_{\mathrm{t}} & =44.97+101.08 \\ \mathrm{~S}^{\prime \prime \prime}{ }_{\mathrm{t}} & =146.05 \\ 8 . & \text { Pemulusan nilai trend pada bulan }\end{array}$ Agustus

$\mathrm{S}^{\prime \prime \prime}{ }_{t}=0.3(154.7)+0.7(146.05)$

$\mathrm{S}^{\prime \prime \prime}{ }_{\mathrm{t}}=46.41+102.23$

$\mathrm{S}^{\prime \prime \prime}{ }_{t}=148.64$

9. Pemulusan nilai trend pada bulan

September

$\mathrm{S}^{\prime \prime \prime}{ }_{\mathrm{t}} \quad=0.3(156.99)+0.7(148.64)$

$\mathrm{S}^{\prime \prime \prime}{ }_{t}=47.09+104.04$

$\mathrm{S}^{\prime \prime \prime}{ }_{\mathrm{t}}=151.13$

10. Pemulusan nilai trend pada bulan Oktober

$\mathrm{S}^{\prime \prime \prime}{ }_{t}=0.3(160.08)+0.7(151.13)$

$\mathrm{S}^{\prime \prime \prime}{ }_{t}=48.02+105.79$

$\mathrm{S}^{\prime \prime \prime}{ }_{\mathrm{t}}=153.81$

11. Pemulusan nilai trend pada bulan November 
$\mathrm{S}^{\prime \prime \prime}{ }_{\mathrm{t}}=0.3(163.38)+0.7(153.81)$

$\mathrm{S}^{\prime \prime \prime}{ }_{\mathrm{t}}=49.01+107.66$

$\mathrm{S}^{\prime \prime \prime}{ }_{\mathrm{t}}=156.67$

12. Pemulusan nilai trend pada bulan

Desember

$\mathrm{S}^{\prime \prime \prime}{ }_{\mathrm{t}} \quad=0.3(164.69)+0.7(156.67)$

$\mathrm{S}^{\prime \prime \prime}{ }_{\mathrm{t}} \quad=49.407+109.66$

$\mathrm{S}^{\prime \prime \prime}{ }_{\mathrm{t}}=159$

13. Pemulusan nilai trend pada bulan Januari

$\mathrm{S}^{\prime \prime \prime}{ }_{\mathrm{t}}=0.3(164.019+0.7(159)$

$\mathrm{S}^{\prime \prime \prime}{ }_{\mathrm{t}}=49.208+113.3$

$\mathrm{S}^{\prime \prime \prime}{ }_{\mathrm{t}}=160.62$
14. Pemulusan nilai trend pada bulan Februari

$\mathrm{S}^{\prime \prime \prime}{ }_{\mathrm{t}}=0.3(164.69)+0.7(162.508)$

$\mathrm{S}^{\prime \prime \prime}{ }_{\mathrm{t}}=49.407+113.756$

$\mathrm{S}^{\prime \prime \prime}{ }_{\mathrm{t}}=161.68$

15. Pemulusan nilai trend pada bulan Maret

$\mathrm{S}^{\prime \prime \prime}{ }_{\mathrm{t}}=0.3(164.138)+0.7(163.163)$

$\mathrm{S}^{\prime \prime \prime}{ }_{\mathrm{t}}=161.8$

16. Pemulusan nilai trend pada bulan April

$\mathrm{S}^{\prime \prime \prime}{ }_{\mathrm{t}}=0.3(162.024)+0.7(163.455)$

$\mathrm{S}^{\prime \prime \prime}{ }_{\mathrm{t}}=161.51$

\section{Perhitungan nilai a pada bulan Januari \\ $\mathrm{a}_{1}=3 \cdot 140-3 \cdot 140+140$ \\ $\mathrm{a}_{1}=140$ \\ 2. Perhitungan nilai a pada bulan} Februari

$\begin{array}{ll}\mathrm{a}_{2} & =3(145.7)-3(141.71)+140.51 \\ \mathrm{a}_{2} & =437.1-425.13+140.51 \\ \mathrm{a}_{2} & =152.48 \\ 3 . & \text { Perhitungan nilai a pada bulan }\end{array}$ Maret

$\mathrm{a}_{3}=3(142.79)-3(142.02)+140.95$

$\mathrm{a}_{3}=428.37-426.06+140.95$

$\mathrm{a}_{3} \quad=143.26$

4. Perhitungan nilai a pada bulan April

$\mathrm{a}_{4}=3(147.05)-3(143.52)+141.71$

$\mathrm{a}_{4}=441.15-430.56+141.71$

$\mathrm{a}_{4} \quad=152.3$

5. Perhitungan nilai a pada bulan Mei

$\mathrm{a}_{5}=3(154.8)-3(146.9)+143.26$

$\mathrm{a}_{5}=464.4-440.7+143.26$

$\mathrm{a}_{5} \quad=166.96$

6. Perhitungan nilai a pada bulan Juni

$\mathrm{a}_{6} \quad=3(147.66)-3(147.12)+144.41$

$\mathrm{a}_{6} \quad=442.98-441.36+144.41$

$\mathrm{a}_{6} \quad=146.03$

7. Perhitungan nilai a pada bulan Juli

$\mathrm{a}_{7}=3(156.46)-3(149.91)+146.05$

$\mathrm{a}_{7} \quad=469.38-449.73+146.05$

$\mathrm{a}_{7} \quad=165.7$

8. Perhitungan nilai a pada bulan Agustus

$\mathrm{a}_{8}=3(165.92)-3(154.7)+148.64$

$\mathrm{a}_{8}=497.76-464.1+148.64$

$\mathrm{a}_{8} \quad=182.3$

9. Perhitungan nilai a pada bulan

September

$$
\begin{array}{ll}
\mathrm{a}_{9} & =3(162.34)-3(156.99)+151.13 \\
\mathrm{a}_{9} & =487.02-470.97+151.13 \\
\mathrm{a}_{9} & =167.18 \\
10 . & \text { Perhitungan nilai a pada bulan }
\end{array}
$$

Oktober

$$
\begin{array}{ll}
\mathrm{a}_{10} & =3(167.33)-3(160.08)+153.81 \\
\mathrm{a}_{10} & =501.99-480.24+153.81 \\
\mathrm{a}_{10} & =175.56 \\
11 . & \text { Perhitungan nilai a pada bulan }
\end{array}
$$

November

$$
\begin{array}{ll}
\mathrm{a}_{11} & =3(171.13)-3(163.38)+156.67 \\
\mathrm{a}_{11} & =513.39-490.14+156.67 \\
\mathrm{a}_{11} & =179.92 \\
12 . & \text { Perhitungan nilai a pada bulan }
\end{array}
$$

Desember

$$
\begin{array}{ll}
\mathrm{a}_{12} & =3(167.79)-3(164.69)+159 \\
\mathrm{a}_{12} & =503.37-494.07+159 \\
\mathrm{a}_{12} & =168.318 \\
13 . & \text { Perhitungan nilai a pada bulan }
\end{array}
$$
Januari

$$
\begin{aligned}
& a_{13}=3(162.453)-3(164.019)+ \\
& 162.508 \\
& a_{13}=487.359-492.057+162.508 \\
& a_{13}=155.85 \\
& 14 . \quad \text { Perhitungan nilai a pada bulan }
\end{aligned}
$$

Februari

$$
\begin{array}{ll}
\mathrm{a}_{14} & =3(164.417)-3(164.69)+163.163 \\
\mathrm{a}_{14} & =162.92 \\
15 . & \text { Perhitungan nilai a pada bulan } \\
\text { Maret } & \\
\mathrm{a}_{15}=3(157.091)-3(164.138)+ \\
163.455 \\
\mathrm{a}_{15}=149.92 \\
16 . \quad \text { Perhitungan nilai a pada bulan } \\
\text { April } \\
\mathrm{a}_{16}=3(157.964)-3(162.024)+ \\
163.019 \\
\mathrm{a}_{16}=152.9
\end{array}
$$


$\square 3 . a) \mathrm{S}^{\prime \prime \prime}{ }_{\mathrm{t}}$

Langkah perhitungan nilai b : $b_{\mathrm{t}} \square \square a / 2(1 \square \square a)(6 \square 5 . a) S^{\prime} \square(10 \square 8 . a) S^{\prime \prime} \square \square(4$

1. Perhitungan nilai b1 pada bulan Januari

$\mathrm{b}_{1}=(0.3 /(2 \times 0.7) \times((6-(5 * 0.3) 140)-(10-(8 \times 0,3) 140)+(4-(3 \times 0.3) 140))$

$\mathrm{b}_{1} \quad=0.214 \mathrm{x}((-204)-(-326)+(-122))$

b1 $=0$

2. Perhitungan nilai b2 pada bulan Januari

$\mathrm{b}_{2} \quad=(0.3 /(2 \times 0.7) \times((6-(5 * 0.3) 145.7)-(10-(8 \times 0,3) 141.71)+(4-(3 \times 0.3) 140.51))$

$\mathrm{b}_{2} \quad=0.214 \mathrm{x}((-212.55)-(-330.104)+(-122.459))$

b2 $=-1,0496$

3. Perhitungan nilai b3 pada bulan Januari

$\mathrm{b}_{3}=(0.3 /(2 \times 0.7) \times((6-(5 * 0.3) 142.79)-(10-(8 \times 0,3) 142.02)+(4-(3 \times 0.3) 140.95))$

$\mathrm{b}_{3} \quad=0.214 \times((-208.185)-(-330.848)+(-122.855))$

b3 $=-0.041$

4. Perhitungan nilai b4 pada bulan April

$\mathrm{b}_{4}=(0.3 /(2 \times 0.7) \times((6-(5 * 0.3) 147.05)-(10-(8 \times 0,3) 143.52)+(4-(3 \times 0.3) 141.71))$

$\mathrm{b}_{4} \quad=0.214 \times((-214.575)-(-334.448)+(-123.539))$

b4 $=-0.784$

5. Perhitungan nilai b5 pada bulan Mei

$\mathrm{b}_{5}=(0.3 /(2 \times 0.7) \times((6-(5 * 0.3) 154.8)-(10-(8 \times 0,3) 146.9)+(4-(3 \times 0.3) 143.26))$

$\mathrm{b}_{5} \quad=0.214 \mathrm{x}((-226.2)-(-342.56)+(-124.934))$

b5 $=-1.834$

6. Perhitungan nilai b6 pada bulan Juni

$\mathrm{b}_{6}=(0.3 /(2 \times 0.7) \times((6-(5 * 0.3) 147.66)-(10-(8 \times 0,3) 147.12)+(4-(3 \times 0.3) 144.41))$

$\mathrm{b}_{6} \quad=0.214 \mathrm{x}((-215.49)-(-343.088)+(-125.969))$

b6 $=0.348$

7. Perhitungan nilai $\mathrm{b} 7$ pada bulan Juli

$\mathrm{b}_{7}=\left(0.3 /(2 \times 0.7) \times\left(\left(6-\left(5^{*} 0.3\right) 156.46\right)-(10-(8 \times 0,3) 149.91)+(43 \times 0.3) 146.05\right)\right)$

$\mathrm{b}_{7} \quad=0.214 \mathrm{x}((-228.69)-(-349.784)+(-127.445))$

b7 $=-1,359$

8. Perhitungan nilai b8 pada bulan Agustus

$\mathrm{b}_{8} \quad=(0.3 /(2 \times 0.7) \times((6-(5 * 0.3) 165.92)-(10-(8 \times 0,3) 154.7)+(4-(3 \times 0.3) 148.64))$

$\mathrm{b}_{8} \quad=0.214 \mathrm{x}((-242.88)-(-361.28)+(-129.776))$

b8 $=-2.434$

9. Perhitungan nilai b9 pada bulan September

$\mathrm{b}_{9} \quad=\left(0.3 /(2 \times 0.7) \times\left(\left(6-\left(5^{*} 0.3\right) 162.34\right)-(10-(8 \times 0,3) 156.99)+(4-(3 \times 0.3) 151.13)\right)\right.$

$\mathrm{b}_{9} \quad=0.214 \mathrm{x}((-237.51)-(-366.776)+(-132.017))$

b9 $=1.8$

10. Perhitungan nilai b10 pada bulan Oktober

$\mathrm{b}_{10}=\left(0.3 /(2 \times 0.7) \times\left(\left(6-\left(5^{*} 0.3\right) 167.33\right)-(10-(8 \times 0,3) 160.08)+(4-(3 \times 0.3) 153.81)\right)\right.$

$\mathrm{b}_{10}=0.214 \mathrm{x}((-244.995)-(-374.192)+(-134.429))$

$\mathrm{b}_{10}=4.03$

11. Perhitungan nilai b11 pada bulan November

$\mathrm{b}_{11}=(0.3 /(2 \times 0.7) \times((6-(5 * 0.3) 171.13)-(10-(8 \times 0,3) 163.38)+(4-(3 \times 0.3) 156.67))$

$\mathrm{b}_{11}=0.214 \mathrm{x}((-250.695)-(-382.112)+(-137.003))$

$\mathrm{b}_{11}=4.3$

12. Perhitungan nilai b12 pada bulan Desember

$\mathrm{b}_{12}=(0.3 /(2 \times 0.7) \times((6-(5 * 0.3) 167.79)-(10-(8 \times 0,3) 164.69)+(4-(3 \times 0.3) 159))$

$\mathrm{b}_{12} \quad=0.214 \mathrm{x}((-245.685)-(-385.25)+(-139))$

$\mathrm{b}_{12}=-1.08$

13. Perhitungan nilai b13 pada bulan Januari

$\mathrm{b}_{13}=\left(0.3 /(2 \times 0.7) \times\left(\left(6-\left(5^{*} 0.3\right) 162.453\right)-(10-(8 \times 0,3) 164.019)+(4-(3 \times 0.3) 162.508)\right)\right.$

$\mathrm{b}_{13}=0.214 \mathrm{x}((-243.679)-(-383.646)+(-142.257))$

$b_{13}=-5.45$ 
14. Perhitungan nilai b14 pada bulan Februari

$\mathrm{b}_{14}=(0.3 /(2 \times 0.7) \times((6-(5 * 0.3) 164.417)-(10-(8 \times 0,3) 164.69)+(4-(3 \times 0.3) 163.163))$

$\mathrm{b}_{14}=0.214 \times((-240.625)-(-385.256)+(-142.847))$

$\mathrm{b}_{14}=-2.02$

15. Perhitungan nilai b15 pada bulan Maret

$\mathrm{b}_{15}=(0.3 /(2 \times 0.7) \times((6-(5 * 0.3) 157.091)-(10-(8 \times 0,3) 164.138)+(4-(3 \times 0.3) 163.455))$

$\mathrm{b}_{15}=0.214 \mathrm{x}((-229.637)-(-383.931)+(-143.109))$

$b_{15}=-7.07$

16. Perhitungan nilai b16 pada bulan April

$\mathrm{b}_{16}=(0.3 /(2 \times 0.7) \times((6-(5 * 0.3) 157.964)-(10-(8 \times 0,3) 162.024)+$

$(4-(3 \times 0.3) 163.019))$

$\mathrm{b}_{16}=0.214 \times((-230.946)-(-378.858)+(-142.717))$

$\mathrm{b}_{16}=-3.31$

Langkah perhitungan nilai $\mathrm{C}: c_{\mathrm{t}} \square \square a^{2} /(1 \square \square a)^{2}\left(S^{\prime} \mathrm{t} \square 2 S^{\prime \prime} \mathrm{t} \square \mathrm{S}^{\prime \prime \prime}{ }_{\mathrm{t}}\right)$

1. Perhitungan nilai $\mathrm{C} 1$ pada bulan Januari

$\mathrm{C}_{1}=0.3^{2} /(1-0.3)^{2} *((140-(2 * 140)+140))$

$\mathrm{C}_{1}=0$

2. Perhitungan nilai $\mathrm{C} 2$ pada bulan Februari

$\mathrm{C}_{2} \quad=0.3^{2} /(1-0.3)^{2} *((142.79-(2 * 141.71)+140.51))$

$\mathrm{C}_{2}=-0.022$

3. Perhitungan nilai $\mathrm{C} 3$ pada bulan Maret

$\mathrm{C}_{3}=0.3^{2} /(1-0.3)^{2} *((142.79-(2 * 142.02)+140.95))$

$\mathrm{C}_{3}=-0.055$

4. Perhitungan nilai $\mathrm{C} 4$ pada bulan April

$\mathrm{C}_{4}=0.3^{2} /(1-0.3)^{2} *((147.05-(2 * 143.52)+141.71))$

$\mathrm{C}_{4} \quad=0.315$

5. Perhitungan nilai C5 pada bulan Mei

$\mathrm{C}_{5} \quad=0.3^{2} /(1-0.3)^{2} *((154.8-(2 * 146.9)+143.26))$

$\mathrm{C}_{5} \quad=0.782$

6. Perhitungan nilai C6 pada bulan Juni

$\mathrm{C}_{6} \quad=0.3^{2} /(1-0.3)^{2} *((147.66-(2 * 147.12)+144.41))$

$\mathrm{C}_{6}=-0.398$

7. Perhitungan nilai C7 pada bulan Juli

$\mathrm{C}_{7}=0.3^{2} /(1-0.3)^{2} *((156.46-(2 * 149.91)+146.05))$

$\mathrm{C}_{7}=0.25$

8. Perhitungan nilai C8 pada bulan Agustus

$\mathrm{C}_{8}=0.3^{2} /(1-0.3)^{2} *((165.92-(2 * 154.7)+148.64))$

$\mathrm{C}_{8}=0.47$

9. Perhitungan nilai C9 pada bulan September

$\mathrm{C}_{9} \quad=0.3^{2} /(1-0.3)^{2} *((162.34-(2 * 156.99)+151.13))$

$\mathrm{C}_{9}=-0.05$

10. Perhitungan nilai $\mathrm{C} 10$ pada bulan Oktober

$\mathrm{C}_{10}=0.3^{2} /(1-0.3)^{2} *((167.33-(2 * 160.08)+153.81))$

$\mathrm{C}_{10}=0.09$

11. Perhitungan nilai C11 pada bulan November

$\mathrm{C}_{11}=0.3^{2} /(1-0.3)^{2} *((171.13-(2 * 163.38)+156.67))$

$\mathrm{C}_{11}=0.188$

12. Perhitungan nilai $\mathrm{C} 12$ pada bulan Desember

$\mathrm{C}_{12}=0.3^{2} /(1-0.3)^{2} *((167.79-(2 * 164.69)+159))$

$\mathrm{C}_{12}=-0.23$

13. Perhitungan nilai $\mathrm{C} 13$ pada bulan Januari

$\mathrm{C}_{13}=0.3^{2} /(1-0.3)^{2} *((162.453-(2 * 164.019)+162.508))$

$\mathrm{C}_{13}=0.184 *-3.077$

$\mathrm{C}_{13}=-0.46$ 
14. Perhitungan nilai $\mathrm{C} 14$ pada bulan Februari

$\mathrm{C}_{14}=0.3^{2} /(1-0.3)^{2} *((164.417-(2 * 164.69)+163.163))$

$\mathrm{C}_{14}=0.184 *-1.8$

$\mathrm{C}_{14}=-0.21$

15. Perhitungan nilai $\mathrm{C} 15$ pada bulan Maret

$\mathrm{C}_{15}=0.3^{2} /(1-0.3)^{2} *((157.091-(2 * 164.138)+163.455))$

$\mathrm{C}_{15}=0.184 *-7.73$

$\mathrm{C}_{15}=-0.48$

16. Perhitungan nilai C16 pada bulan April

$\mathrm{C}_{16}=0.3^{2} /(1-0.3)^{2} *((157.964-(2 * 162.024)+163.019))$

$\mathrm{C}_{16}=0.184^{*}-3.065$

$\mathrm{C}_{16}=-0.2$

Hasil peramalan untuk bulan Mei adalah :

$\mathrm{F}_{\mathrm{t}}+\mathrm{m}=\mathrm{a}_{\mathrm{t}}+\mathrm{b}_{\mathrm{t}}(1)+1 / 2 \mathrm{c}_{\mathrm{t}}(1)$

$=152.9+(-3.31)(1)+(1 / 2 *-0.2(1))$

$=152.9-3.31-0.1$

$=149.49$

Hasil peramalan pada untuk periode ke-17 adalah 149.49 atau sama dengan 149 unit.

\subsection{Hasil}

1. Tampilan Form Hasil Peramalan

Tampilan ini merupakan tampilan form Hasil Peramalan yang berfungsi untuk mengisi datadata Hasil Peramalan. Berikut gambar form Hasil Peramalan ditunjukkan pada 3 :

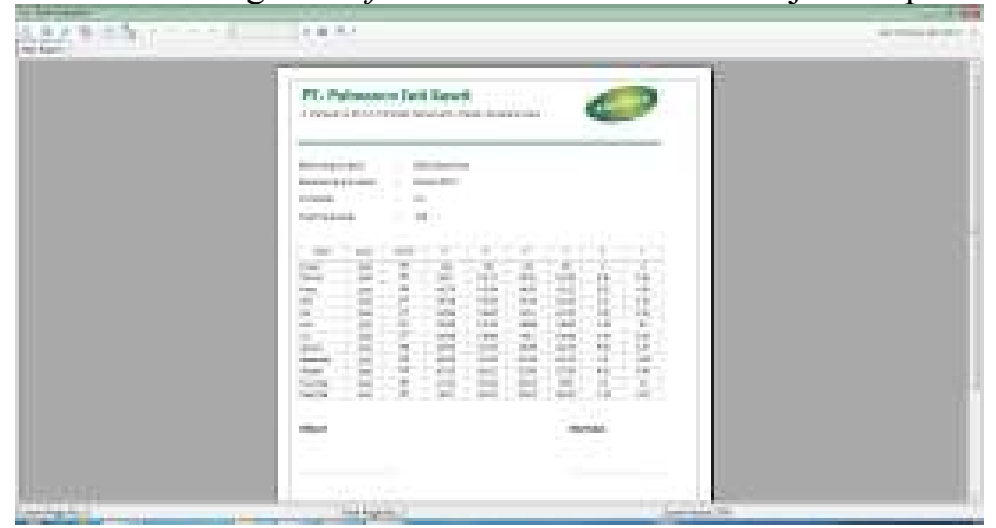

Gambar 3 . Tampilan Form Hasil Peramalan

\section{Tampilan Form Bibit}

Tampilan ini merupakan tampilan form laporan bibit yang berfungsi untuk mengisi data-data laporan bibit. Berikut gambar form laporan bibit ditunjukkan pada 4:

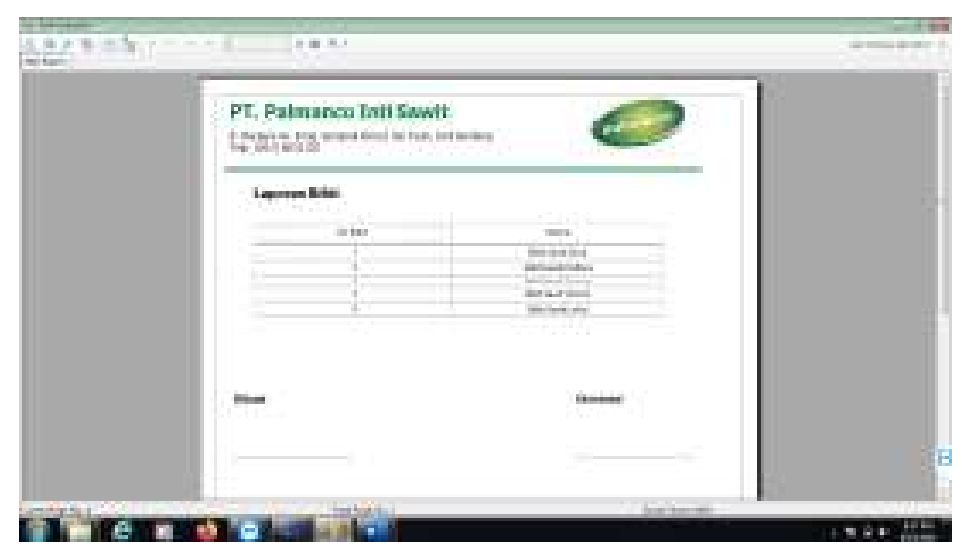

Gambar 4. Tampilan Form Laporan Bibit 


\section{Tampilan Form Penanaman Bibit}

Tampilan ini merupakan tampilan form laporan penanaman bibit yang berfungsi untuk mengisi data-data laporan penanaman bibit. Berikut gambar form laporan penanaman bibit ditunjukkan pada 5 :

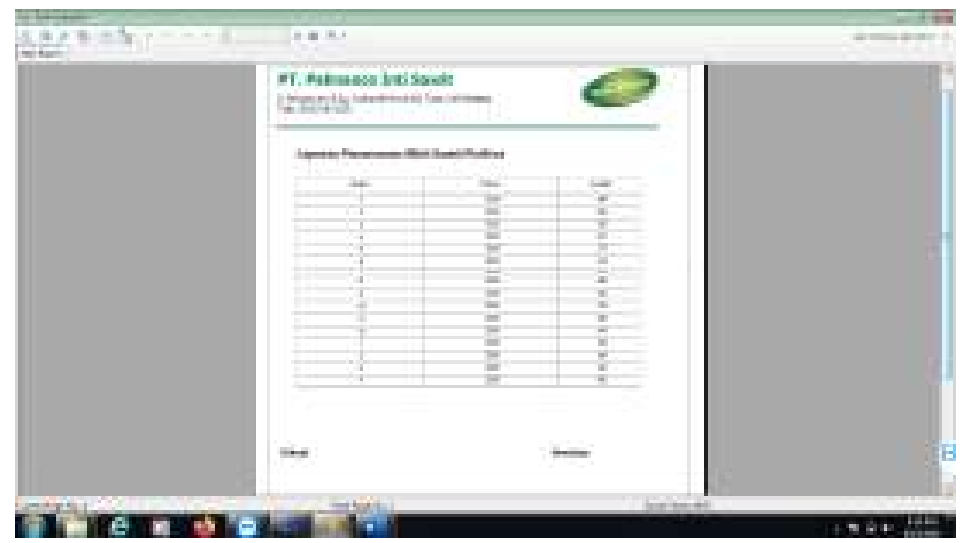

Gambar 5. Tampilan Form Laporan Penanaman Bibit

\section{KESIMPULAN}

Adapun kesimpulan dari Laporan penelitian ini adalah sebagai berikut :

1. Diterapkannya metode Triple Exponential Smoothing dalam Prediksi Penanaman Bibit Kelapa Sawit Pada PT. Palmanco Inti Sawit memperoleh hasil prediksi Penanaman Bibit Kelapa Sawit yang efektif.

2. Terciptanya sistem aplikasi prediksi Penanaman Bibit Kelapa Sawit dengan menggunakan aplikasi Visual Studio 2020 dan database Sql Server 2008.

3. PT. Palmanco Inti Sawit dapat mengurangi tingkat kesalahan dalam penentuan prediksi penanaman bibit kelapa sawit dan pembuatan laporan yang dapat mempermudah dan mempercepat user dalam melakukan pendataan Penanaman Bibit Kelapa Sawit.

4. Sistem yang dirancang dapat membantu perusahaan dalam mengatasi kendala peramalan penanaman bibit kelapa sawit pada periode masa yang akan datang.

\section{SARAN}

Adapun saran-saran yang akan penulis usulkan untuk meningkatkan laporan penelitian ini, adalah sebagai berikut :

1. Sistem yang dibangun diharapkan dimasa yang akan mendatang dapat dikembangkan lagi kepada pelanggan secara online.

2. Diharapkan sebaiknya jika terjadi kerusakan pada server data tidak akan terhapus.

3. Diharapkan kedepannya perusahaan untuk siap melakukan penanaman bibit kelapa sawit secara online agar konsumen lebih tertarik.

4. Sebaiknya dilakukan pengembangan sistem yang berbasis client server sehingga mempermudah perusahaan dalam melakukan prediksi penanaman bibit kelapa sawit tiap periodenya.

5. Sebaiknya dilakukan proses back-up data setiap saat untuk menghindari kerusakan atau kehilangan data.

\section{UCAPAN TERIMA KASIH}

Peneliti mengucapkan terima kasih yang sebesar-besarnya kepada Universitas Potensi Utama yang telh mebantu penulis dalam menyelesaikan penelitian ini. 


\section{DAFTAR PUSTAKA}

[1] Nurlifa, A., \& Kusumadewi, S. (2017). Sistem Peramalan Jumlah Penjualan Menggunakan Metode Moving Average Pada Rumah Jilbab Zaky. INOVTEK Polbeng-Seri Informatika, 2(1), 18-25.

[2] Utama, C. A. (2016). Pengembangan si stok barang dengan peramalan menggunakan metode double exponential smoothing (studi kasus: PT. Tomah Jaya Elektrikal). Jurnal Informatika Polinema, 2(4), 147-147.

[3] Linda, D. (2016). Analisis Sistem Informasi Pengawas Keamanan dan Kesehatan Makan pada Dinas Kesehatan Kota Bandar Lampung. EXPERT: Jurnal Manajemen Sistem Informasi dan Teknologi, 6(2).

[4] Riska Perdana, F. (2016). Perbandingan Metode DES (Double Exponential Smoothing) dengan TES (Triple Exponential Smoothing) pada Peramalan Penjualan Rokok (Studi Kasus Toko Utama Lumajang) (Doctoral dissertation, universitas muhammdiyah jember).

[5] Junaidi, J. (2014). Analisis Hubungan Deret Waktu untuk Peramalan.

[6] Munte, M. H. M. (2016). Sistem Informasi Akuntansi. Edisi Pertama Universitas HKBP Nommensen

[7] Utami, M. C., \& Hutomo, Y. T. (2014). Penerapan Waterfall Dalam Analisis dan Perancangan Sistem Informasi Manajemen Dokumen Surat Menyurat Pada Bank BJB Kantor Cabang BSD Tangerang. Jurnal Sains, Teknologi dan Industri, 12(1), 129135. 